\title{
Music for the Moors and Christians \\ Festivities as Intangible Cultural \\ Heritage: A Specific Genre for Wind \\ Bands in Certain Spanish Regions
}

\author{
Daniel Catalá-Pérez $\mathbb{D}$ and Gabino Ponce-Herrero $\mathbb{D}$
}

\section{Introduction}

The history of wind bands and their music is a history of vindication (Dubois et al., 2013, p. xi; Reily \& Brucher, 2013, p. 3). More than a hundred years ago, Parès (1898) wrote in the prologue of the first treatise on band orchestration that "... we must seek the necessary means to give fanfare music, as well as harmony music (wind bands), the relevance that belongs to them, and we hope to show that, like the symphony orchestra, they can translate the composer's inspirations and be worthy of his attention ...". Just three years ago, Pascual-Vilaplana (2017) spoke about the situation in Spain stating that if "the presence of a band in important music festivals continues to surprise us even in 2017, this is symptomatic of the road ahead. [...] The normality should be to take advantage of our professional wind bands, both civil and military, as well as the amateur ones, to better use their artistic potentialities. [...] we must be able to make ourselves visible, to assert ourselves with our work and not to give into ignorance".

The lack of knowledge about the history of wind bands and the economic, cultural and social importance that their activity implies, has become a serious obstacle to the correct management of the huge and highly valuable cultural heritage that the entire wind band music corpus represents in Spain (Cipollone Fernández, 2016, p. 162). In fact, the international bibliography barely includes studies on the vast repertoire that this Spanish music segment constitutes (studies such as Reily \& Brucher, 2013, which ignore the Spanish case, are a clear example), nor is there a review in Spanish

\footnotetext{
D. Catalá-Pérez ( $₫)$

Universitat Politècnica de València, Valencia, Spain

e-mail: dacapre@ade.upv.es

G. Ponce-Herrero

Universidad de Alicante, Alicante, Spain

e-mail: gabino.ponce@ua.es 
of the international wind music repertoire. In fact, in Spain, research on wind band music has usually been included in the study of popular folklore or has been limited to monographic studies on some specific wind bands, composers and, to a lesser extent, directors (Cipollone Fernández, 2016, pp. 159-161).

Wind band music and the role of wind bands require an in-depth study beyond beliefs, customs and clichés in order to give them the value they deserve. This is especially relevant for two reasons: the wind band model in Spain, as we will see later, differs from other international models as it is a means for the cultural expression of local identity and autonomy, given that bands are intricately linked to local popular festivities (Dubois et al., 2013, p. xiv). In addition, the management and organisation model of these bands through the so-called musical societies, which constitute one of the most important association movements in Spain, is also especially interesting.

Their relevance in the Valencian Region is especially salient, with a total of 555 musical societies in a territory with 542 municipalities, $71 \%$ of which have less than 5,000 inhabitants. (INE, 2020). Such is the importance that these entities have for Valencian society that the Regional Government declared them as an Asset of Intangible Cultural Interest for the Valencian Region in 2018, thus giving them special protection. ${ }^{1}$ The link between musical societies and popular Valencian festivals such as Fallas and Fogueres is significant, but it is especially relevant in terms of the Moors and Christians festivals. These are, in turn, one of the most important festive events in the region, present in at least 181 municipalities (Alcaraz Santonja, 2019). In 2015, they were declared as an Intangible Asset of Local Relevance by the Valencian Government. $^{2}$

Since the end of the nineteenth century, the symbiosis of both phenomena has created an exclusive musical repertoire for these popular festivals that include several thousand compositions. Thus, numerous authors have demanded recognition for the specific genre of wind band music (Botella-Nicolás, 2014; Pascual-Vilaplana, 2001). In the case of the Valencian Region, given the importance of the musical society phenomenon, some studies have focused on their functioning, their role in Valencian society and their economic impact (e.g. Rausell, 2018). Additionally, authors such as Botella-Nicolás $(2014,2018)$ and Cipollone-Fernández (2017) have focused on the study of the musical corpus that has emerged as a result of this relationship and its cultural and artistic value. However, in general terms, there is a clear need to delve deeper into these research areas (Rausell, 2018, p. 5).

This chapter makes a brief approach to the origins and evolution of both wind bands and the Moors and Christians festivals, especially in the Valencian context, tracing the lines that connected both phenomena at a specific moment in history. The indissoluble relationship that has united them since then has created a musical genre that has not only become one of the most recognisable signs of Valencian society's

\footnotetext{
${ }^{1}$ DECREE 68/2018, of 25 May, of the Valencian Regional Government, under which the Valencian popular musical tradition materialised by the musical societies of the Valencian Region is declared to be of intangible cultural interest.

${ }^{2}$ ORDER 50/2015, of 13 May, of the Valencian Region's Ministry of Education, Culture and Sports, declaring the Moors and Christians festivities of the Valencian Region as an Intangible Asset of Local Relevance.
} 
identity, but also a treasure of its intangible cultural heritage, and a fundamental part of the economic activity of musical societies in the context of what certain authors call the ecosystem of the Moors and Christians cluster (Martínez Puche et al., 2019).

\section{The Moors and Christians Festivities: A Global Phenomenon with Local Peculiarities}

\subsection{Origin and Spread of the Phenomenon of Moors and Christians Festivals}

The Moors and Christians festivals in their multiple modalities constitute a complex phenomenon, whose study and comprehensive understanding require an approach from diverse perspectives including anthropology and ethnology (Martínez Pozo, 2015), sociology (Alcaraz Santonja, 2019), ethnography and history (Domene Verdú, 2018), economy (Latorre Ruiz, 2019; Perles Ribes \& Díaz Sánchez, 2019), literature (Domene Verdú, 2018) and musicology (Botella-Nicolás, 2018; CipolloneFernández, 2017). A factor that further increases the complexity of phenomenon must also be added: the expansion of Moorish and Christian festivals throughout the world (Catalá-Pérez, 2017). ${ }^{3}$

Brisset Martín (2001) affirms that "in essence, the Moors and Christians festival consists of a popular theatre performance [...], expressing the fight between the side of the heroes (the Christians) and that of the enemies (the Moors) for the possession of a collective good, through actions and / or discussions" (Brisset Martín, 2001). In any case, the origin of these representations comes from the dramatisation through dance of the fights between Moorish and Christian troops which were performed in royal celebrations to commemorate certain victories during the time known as the Reconquest in the Iberian Peninsula (Amades, 1966; Brisset Martín, 1988; CataláPérez, 2012).

For many researchers, the first historical reference mentioning a battle dramatised as a dance took place in Lleida in 1150 during the wedding of Ramon Berenguer IV, Count of Barcelona, and Petronila, daughter of Ramiro I, King of Aragon (Brisset Martín, 1988). For other authors, the first reference is the representation of a naval battle between two galleys of Christians and Saracens that Peter IV, known as the Ceremonious, organised in 1373 to commemorate the visit of his future daughter-inlaw Martha de Armanyac to Barcelona (Massip, 2015). However, the truth is that these representations were already contemporaneous with the battles they commemorated

\footnotetext{
${ }^{3}$ In fact, in recent years, there has been interest in approaching the study of Moors and Christians festivals from an international perspective. Proof of this is the different scientific events that have been organised in recent years: the International Congress on the Komedya Fiesta (as the Moors and Christians festivals are known in the Philippines) held in 2008 at the University of the PhilippinesDiliman and the different international congresses held in Spain in 2010 (in Ontinyent, Valencia), 2016 (University of Alicante) and 2018 (Villena, Alicante) (Catalá-Pérez, 2017).
} 
and up to the fifteenth century they were organised almost exclusively on the occasion of royal festivals.

Even so, from the late fourteenth century onwards, the Catholic Church saw an excellent evangelising vehicle in the representation of the confrontation between the Christian and Muslim faith. Soon, elements of this confrontation were incorporated into certain religious festivities such as Corpus Christi (certain dances are still preserved in some localities) including the representation of moralising plays on the victory of the Christian faith over Islam. In addition, with the arrival of the Spanish in America, many of these plays were used in their missions to Christianise the new territories (Catalá-Pérez, 2012). The truth is that with the expansion of the Spanish empire, the Moors and Christians festival reached many of the territories under their dominion, sometimes in Europe as royal celebrations, and in overseas territories as tools of religious-cultural imposition. In certain places, the festival continues to be celebrated whilst in others it has disappeared, although testimonies of its existence remain. In other places, the original representations evolved until they became rituals that differ significantly from the original. ${ }^{4}$

\subsection{The Valencian Model of the Moors and Christians Festivities}

In the Spanish context, the end of the sixteenth century and especially the seventeenth century saw the Moors and Christians become the most widespread festivity. On the one hand, the changes caused by the Counter-Reformation and the Council of Trent (1545-1563) introduced acts related to the historical representation of the battles between Moors and Christians in the formerly, solely religious, patron saint festivities in numerous localities. Before this time, the Moors and Christians festivities had been organised by local guilds. In addition, the participation of local militias ${ }^{5}$ in the festivities became widespread. The militias accompanied the patrons in the processions firing their arquebuses and also represented each of the sides (Moors and Christians) in simulated battles (Domene Verdú, 2018, p. 564). Additionally, from the seventeenth century onwards, in addition to the Reconquest, the festivities began to represent other historical events such as the attacks by Berber pirates on the shores of the Mediterranean and the expulsion of Spanish Moorish descendants in 1609.

\footnotetext{
${ }^{4}$ Various authors (Brisset Martín, 1988, 2001; Domene Verdú, 2018; Martínez Pozo, 2015; Warman Gryj, 1972) have studied the influences and historical circumstances that have marked the evolution of the primitive representations of Moors and Christians until they became, over the centuries, one of the most widespread festive manifestations in the world, present, in one way or another, on the five continents (Catalá-Pérez, 2017).

${ }^{5}$ The term militia refers to "a type of armed organization made up of men to defend a territory, serve as a reserve force, maintain public order or fight for a specific political cause" (Contreras Gay, 1992, p. 75). The participation of the militias in the patron saint festivities of numerous localities became widespread as of the sixteenth century, with this participation even becoming compulsory by way of military manoeuvres to keep said militias trained (Martínez Pozo, 2015, p. 118).
} 
Thus, the representations of Moors and Christians became popular and spread to the smaller towns. At the end of the seventeenth and early eighteenth centuries, we can already find references to some of the most well-known Moors and Christians festivals in the Valencian Region, such as those of Alcoy and Villena (Domene Verdú, 2018).

In the nineteenth century, a series of circumstances ended up shaping the Moors and Christians festival as we know it today in the Valencian Region, differentiating it from the festive model in other regions. Firstly, the division of the participants on the Moors and Christians sides into comparsas or filaes was generalised. ${ }^{6}$ Secondly, thanks to the creation of these comparsas or filaes, the military parades that had already been performed by the militias took on special relevance.

The greater variety of characters made these parades more spectacular and, at the same time, generated the need to add new pieces to the musical repertoire to accompany the comparsas, beyond the traditional military marches. Thus, at the end of the nineteenth century, the first specific compositions for these parades were written (Cipollone-Fernández, 2017), helping the entradas ${ }^{7}$ to gain prominence in the festive calendar. At this point, the Valencian Moors and Christians festival model was configured as it remains to this day: historical events (discussions and simulated battles) alternating with religious events (processions and masses) and military acts (parades and firing of arquebuses) (Domene Verdú, 2018, p. 56). Institutions such as the National Union of Festive Entities (UNDEF, in its Spanish acronym), made up of towns and cities that celebrate this festive model, have been working to preserve them since 1974. In this sense, the Valencian Regional Government recognised their importance to Valencian society by declaring them as an Intangible Asset of Local Relevance in 2015.

Finally, the most recent history of the Moors and Christians festivities in Valencia is fundamentally marked by three events: first, the great expansion of the festival since the beginning of the current democratic period, especially in the northern area of the province of Valencia; secondly, the search for the features that characterise the identity of each population through the recovery of local history; and finally, the design of the Moors and Christians festival as a visual and musical spectacle beyond its historical significance, which has led many municipalities to only incorporate processions such as the entrada into their festive calendar. Thus, Alcaraz Santonja

\footnotetext{
${ }^{6}$ The comparsas or filaes are groups of people who represent different historical identities, sometimes linked to the historical origin of the representations (e.g. Templars, Hospitallers, Crusaders, etc., on the Christian side, and Berbers, Mudejars, Bedouins, etc., on the Moorish side). Certain events of a political nature (the growth of certain ideologies), military nature (e.g. the Carlist wars, the War of Independence and the Morocco war) and a cultural nature (Romanticism and the arrival of the cinema) led to the appearance of comparsas such as smugglers, farmers, students, corsairs, buccaneers and musketeers who, far from being medieval stereotypes, represent idealised figures of the historical moment in which they were included in the representations. This fact accentuated the popular nature of the Moors and Christians festivals.

${ }^{7}$ Entrada (literally, entrance, in English) is the name given to the parades of the Moorish and Christian troops, symbolising the moment in which they "enter" the town to start the fight.
} 
Table 1 Formal types of Moors and Christians festivals in Spain

\begin{tabular}{l|l}
\hline Formal Type & Description \\
\hline Modern Moors and Christians festival & $\begin{array}{l}\text { A type that originated at the end of the eighteenth } \\
\text { century and the middle of the nineteenth century } \\
\text { which is characterised by a sequence that } \\
\text { includes historical, religious and military acts, } \\
\text { and by an organisational structure divided into } \\
\text { filaes/comparsas that go beyond the traditional } \\
\text { division of Moors and Christians }\end{array}$ \\
\hline $\begin{array}{l}\text { Entrada of Moors and Christians as a festive } \\
\text { complement }\end{array}$ & $\begin{array}{l}\text { A type that has emerged in recent decades based } \\
\text { on a single act, the Entrada of Moors and } \\
\text { Christians, which is embedded within the patron } \\
\text { saint festivals of a town or neighbourhood, but } \\
\text { which does not respond to the dramatic } \\
\text { sequential logic of events that characterise the } \\
\text { previous model }\end{array}$ \\
\hline Traditional Moors and Christians festival: & $\begin{array}{l}\text { A type that has maintained its basic ritual } \\
\text { sequence unaltered for decades and even } \\
\text { centuries, to which the main two features }\end{array}$ \\
& $\begin{array}{l}\text { identified in the previous types have not been } \\
\text { incorporated: the Entrada and the division of the } \\
\text { festival into filaes/comparsas }\end{array}$ \\
\hline Moors and Christians dances & $\begin{array}{l}\text { A type that consists of a spoken dance where a } \\
\text { ritual confrontation between two groups of } \\
\text { dancers is symbolised and includes a fight } \\
\text { between Moors and Christians in one of its parts }\end{array}$ \\
\hline
\end{tabular}

Source Authors' own, based on Alcaraz Santonja (2019)

(2019) classified the Moors and Christians festivals in Spain according to their formal characteristics, differentiating between the four types shown in Table 1.

Alcaraz Santonja (2019) identified 359 festive representations of Moors and Christians based on these formal types, distributed by region, as shown in Table 2. This shows that the most widespread formal type is that of the modern festival in the Valencian Region. In addition, the Valencian area is also where the entrada type as a festive complement has developed the most. These are precisely the two models where wind bands are especially important elements in the festival.

The festival as we know it in Valencian towns is capable of creating a social environment around it in which people can find personal development. It is also a source of cultural, economic and social wealth for any town where it is celebrated. Accordingly, the Moors and Christians festivities in the twenty-first century are based on new contemporary values that go beyond classic traditional, religious and historicist ones (Martínez Pozo, 2015):

- The feeling of belonging to a community.

- The cyclical nature of the festivities, as opposed to the routine of everyday life, has the virtue of endowing them with their own time, which can imply an acceleration or a deceleration of experiences. 
Table 2 Distribution of the festive representations of Moors and Christians in Spain

\begin{tabular}{|c|c|c|c|c|c|c|c|}
\hline \multirow[t]{2}{*}{ Region } & \multirow[t]{2}{*}{ Province } & \multicolumn{4}{|c|}{ Formal types } & \multirow{2}{*}{\multicolumn{2}{|c|}{ Total }} \\
\hline & & $\begin{array}{l}\text { Modern } \\
\text { Festival }\end{array}$ & $\begin{array}{l}\text { "Entrada" as } \\
\text { Complement }\end{array}$ & $\begin{array}{l}\text { Traditional } \\
\text { Type }\end{array}$ & Dances & & \\
\hline \multicolumn{2}{|l|}{ Andalusia } & 8 & 2 & 66 & & \multicolumn{2}{|l|}{76} \\
\hline \multicolumn{2}{|l|}{ Aragon } & & 2 & 2 & 34 & \multicolumn{2}{|l|}{38} \\
\hline \multicolumn{2}{|c|}{ Castile La Mancha } & 4 & 2 & 11 & 1 & \multicolumn{2}{|l|}{18} \\
\hline \multicolumn{2}{|c|}{ Castile and Leon } & & & 4 & 1 & \multicolumn{2}{|l|}{5} \\
\hline \multicolumn{2}{|c|}{ Catalonia } & 1 & 1 & 4 & 9 & \multicolumn{2}{|l|}{15} \\
\hline \multicolumn{2}{|l|}{ Madrid } & & 1 & & & \multicolumn{2}{|l|}{1} \\
\hline \multirow{3}{*}{$\begin{array}{l}\text { Valencian } \\
\text { Region }\end{array}$} & Alicante & 53 & 23 & & 3 & 79 & \multirow[t]{3}{*}{181} \\
\hline & Castellon & & 6 & & 1 & 7 & \\
\hline & Valencia & 38 & 53 & 2 & 2 & 95 & \\
\hline \multicolumn{2}{|c|}{ Extremadura } & & 1 & & & \multicolumn{2}{|l|}{1} \\
\hline \multicolumn{2}{|c|}{ Galicia } & & & 5 & & \multicolumn{2}{|l|}{5} \\
\hline \multicolumn{2}{|c|}{ Balearic Islands } & 1 & & 3 & & \multicolumn{2}{|l|}{4} \\
\hline \multicolumn{2}{|c|}{ Canary Islands } & & & 2 & & \multicolumn{2}{|l|}{2} \\
\hline \multicolumn{2}{|c|}{ Navarre } & & & & 1 & \multicolumn{2}{|l|}{1} \\
\hline \multicolumn{2}{|c|}{ Basque Country } & & & & 1 & \multicolumn{2}{|l|}{1} \\
\hline \multicolumn{2}{|c|}{ Murcia } & 10 & & 1 & & \multicolumn{2}{|l|}{11} \\
\hline \multicolumn{2}{|l|}{ Totals } & 115 & 91 & 100 & 53 & \multicolumn{2}{|l|}{359} \\
\hline
\end{tabular}

Source Authors' own based on Alcaraz Santonja's data (2019)

- Festivals are a means of integration that helps to create strong bonds of friendship.

- They are a social phenomenon, a space for multi- and intercultural coexistence between people, men and women of different social origins, generations, cultures and even religions.

- They are festivals that have been adapted to the different historical moments and different territories where they are rooted.

In addition, in the case of the Valencian model's festivals, despite the search for historicity, postmodernity has opened a path to a game of fantasy where the visual and performing arts have taken on great importance. The influence of historical, epic and, above all, fantastic cinema, as well as contemporary theatre, has created mythological figures that have become part of the parades giving them a new appearance and culture, without neglecting the inheritance received from many centuries of history.

In this context, the Moors and Christians festivals are a very relevant phenomenon from an economic point of view for the Valencian Region, firstly, from the perspective of their impact on the municipalities in which they are held. In this sense, some studies have quantified this impact at exceeding $€ 20$ million in a town like Alcoy (Latorre Ruiz, 2019), $€ 8$ million in Elda (Pedrero Rico, 2016) and $€ 5.5$ million in Calpe (Perles Ribes, 2006), and secondly, as a cluster which authors such as Martínez Puche 
et al. (2019) referred to as "the ecosystem of the Moors and Christians festivals" in which they identified microclusters, such as festive crafts, which include elements that also generate economic activity such as monumental heritage, accommodation, regulations, music, the participatory nature of festivals, gastronomy, history and identity, communication and marketing.

\section{Wind Bands: Approach to Their Origin and Evolution}

According to the British National Federation of Musical Societies (2017), "a wind band is composed of instruments where the sound is produced by making a column of air vibrate inside the instrument, so that's wind and brass instruments". It could be thought "that the word wind means just woodwind instruments, but in this case the word wind refers to the way the sound is produced, rather than being a short version of the word woodwind". In a very simple way, a wind band is basically an orchestra with the strings removed and saxophones added. Obviously, the correct definition is more complex, but there is no standardised line-up for wind bands, so parts are often omitted and/or included in other parts.

In the woodwind section, "the wind band uses extra clarinet parts to replace the missing strings, with multiple players on each part [...]. There are flute, piccolo, oboe and bassoon parts, and the addition of four saxophone parts who help to fill in the middle register harmonies that come between the high woodwind/brass melody instruments and the very low bass instruments". The brass section includes the standard orchestral line-up of horns, trumpets, trombones and tubas. Cornets and/or extra trumpets are usually required, and euphoniums are added to help the saxophones complete the middle harmonies. Two tubas, often doubling in octaves, create a strong bass line. Finally, in addition to wind instruments, there is also a percussion section. Typically, a wind band percussion section will have more to do than in a symphony orchestra, and the players are required to switch between several instruments in the same piece. One of the main characteristics of wind bands is that they are great for outdoor performances, because their sound carries easily without additional amplification (National Federation of Musical Societies, 2017).

The origin of wind bands in the Middle Ages comes from references to groups of minstrels that played in religious acts and the instrumental groups that served as court entertainment (Rhodes, 2007). Later, in the Renaissance, the Alta Capella formation was common as a group destined to perform at public events and large religious celebrations, generally outdoors (Mayor Catalá, 2011). But since the Alta Capella, there was no type of grouping formed exclusively by wind instruments that enjoyed popularity until the appearance of the Harmoniemusik in the Classicism of the eighteenth century (Rhodes, 2007).

The nineteenth century was, without a doubt, one of the most important and fruitful periods in the development and birth of wind bands, as we know them today. There were two clear influences: firstly, the aforementioned Harmoniemusik movement, which diversified the instrumental wind groups of the eighteenth century, both 
in the ceremonies of European aristocratic houses and in the most popular festive manifestations, and secondly, the military bands that aroused national sentiment and moved the masses, which popularised them among the population at mass events. The major influence that the Band of the Turkish Janissaries had in this regard in Europe should be mentioned here (Reily \& Brucher, 2013).

In the Spanish state, from the end of the nineteenth century, popular wind bands began to be created, in many cases, by retired military musicians. These bands known as "militia bands" were dressed in military-style suits. Documentation exists of the creation of popular wind bands such as the Wind Music Band of Irún (1784), that of Xativa (Valencia, 1800), Muro (Alicante, 1801), Manresa (Barcelona, 1815), Banda Primitiva de Llíria (Valencia, 1819), Banda de Éibar (1831) and the Banda de Bergara (1832) (Pascual-Vilaplana, 2020).

The evolution of wind instruments, the invention of new ones (such as those patented by Adolph Sax in 1845) and the interest generated by highly relevant composers, led wind and percussion bands to advance. Their roles ranged from performing religious music in temples and/or processions, to dancing and symphonic concerts, as well as performing arrangements of symphonic works, operas and zarzuelas. However, symphonic music for bands in Spain was relegated to suites for waltzes and polkas, with no relevant echo in concert halls. The melodies of overtures, operas, symphonies and zarzuelas were well known in towns thanks to wind bands, and not to their orchestral originals. This relegated the use of original wind band music which, although it was composed, had little influence beyond regionalist and folkloric works. Hence, the importance of the appearance in the nineteenth century of the widespread band movement that emerged in the Valencian Region: the music for the Moors and Christians festival (Pascual-Vilaplana, 2011).

\subsection{The Valencian Model of Musical Societies}

Musical societies make up an association movement known mainly as a wind band movement, given that the wind band is the original artistic unit around which each musical society is shaped. The management model of bands through musical societies is widely extended in Spain. According to data from the Spanish Confederation of Musical Societies (COESSM, in its Spanish acronym) ${ }^{8}$ at the end of 2019, there were 14 regional federations in Spain representing a total of 1,513 musical societies, with around 112,000 musicians (most of them amateurs), over 120,000 students in their music schools and more than 1,000,000 members. Table 3 shows the number of musical societies by regional federations and autonomous regions in Spain.

The Valencian Region has the largest number of musical societies in Spain (more than a third of the total, according to the table above) and constitutes an internationally studied model (Cohen, 1997, 1999; Molle, 2008). Valencian musical societies participate in cultural events and celebrations of all kinds throughout the year. They

\footnotetext{
${ }^{8}$ Information available on the COESSM website (https://coessm.org/).
} 
Table 3 Number of Spanish musical societies by region

\begin{tabular}{|c|c|c|}
\hline REGION & REGIONAL FEDERATION & SOCIETIES \\
\hline Andalusia $^{a}$ & Federación de Bandas de Música de Andalucía & 337 \\
\hline Aragon & $\begin{array}{l}\text { Federación Aragonesa de Sociedades Musicales y Escuelas } \\
\text { de Música Amateurs }\end{array}$ & 50 \\
\hline Asturias ${ }^{\mathrm{b}}$ & & 14 \\
\hline Balearic Islands & $\begin{array}{l}\text { Federación Balear de Bandas de Música y Asociaciones } \\
\text { Musicales }\end{array}$ & 37 \\
\hline \multirow[t]{2}{*}{ Canary Islands } & Federación Gran Canaria de Bandas de Música & \multirow[t]{2}{*}{52} \\
\hline & Federación Tinerfeña de Bandas de Música & \\
\hline Cantabria $^{\mathrm{b}}$ & & 1 \\
\hline Castile La Mancha & $\begin{array}{l}\text { Federación Castellano-Manchega de Sociedades Musicales } \\
\text { (incluye la Federación Provincial de Bandas de } \\
\text { Guadalajara) }\end{array}$ & 91 \\
\hline Castile and Leon & $\begin{array}{l}\text { Federación Castellano-Leonesa Asociaciones Musicales, } \\
\text { Bandas y Escuelas Música }\end{array}$ & 27 \\
\hline Catalonia & Federación Catalana de Sociedades Musicales & 44 \\
\hline Valencian Region & $\begin{array}{l}\text { Federación de Sociedades Musicales de la Comunidad } \\
\text { Valenciana }\end{array}$ & 555 \\
\hline Extremadura & Federación Extremeña de Bandas de Música & 63 \\
\hline Galicia & Federación Gallega de Bandas de Música Populares & 88 \\
\hline Rioja $^{\mathrm{b}}$ & & 1 \\
\hline Madrid & $\begin{array}{l}\text { Federación Regional de Sociedades Musicales, Comunidad } \\
\text { de Madrid }\end{array}$ & 27 \\
\hline Murcia & Federación de Bandas de Música de la Región de Murcia & 40 \\
\hline Navarre & Federación Navarra de Bandas de Música & 59 \\
\hline Basque Country ${ }^{b}$ & & 27 \\
\hline \multicolumn{2}{|l|}{ TOTAL } & 1,513 \\
\hline
\end{tabular}

Source Authors' own taken from https://coessm.org/

anformation about Ceuta and Melilla is included

${ }^{\mathrm{b}}$ There are no regional federations in these autonomous regions

are a clear example of a successful social project that is not only long-lasting in time but is constantly growing, and it is a social movement considered by the Regional Government as a characteristic feature identifying Valencian society. Accordingly, in 2018, the popular Valencian musical tradition materialised by musical societies was declared as an Asset of Intangible Cultural Interest of the Valencian Region.

Currently, Valencian musical societies have much more than just a wind band as their only artistic unit. They also have other groups such as orchestras, chamber orchestras, big bands, choirs and other instrumental groups. In any case, and although it is obvious that the wind band is the most relevant group in their artistic spectrum in the vast majority of cases, the Valencian Region Federation of Musical Societies 
(FSMCV, in its Spanish acronym) has established a definition of the concept of musical society:

- Private entities with an adequate and sufficient social mass.

- Non-profit entities, with a legal form, legally constituted and recorded in a public registry, with independent control over their governance and management.

- Entities related to the society in which they operate and with which they work closely.

- Entities with a music school that guarantees the sustainability of the musical project.

- Entities with at least one working artistic musical group.

Valencian musical societies are open societies. In recent years, they have adapted to the times without losing their essence and they have become not only sociocultural spaces, but also places for the exchange of ideas and opinions among people of all social, cultural and religious classes. This is one of the keys to their survival as an association movement. In addition, musical societies, and wind bands as their main artistic unit, carry out a fundamental task to preserve Valencian musical heritage through different activities:

- The educational activities that enable them to nurture their musical project and to provide flexible, high-quality musical training to neighbouring society.

- The many cultural activities that they organise, which include concerts, exchange programmes with other municipalities, participation in competitions, participation in European projects and the organisation of festivals.

- Their fundamental contribution to Valencian society's way of life through their connection to traditional local festivals. The Moors and Christians festivities cannot be understood without the wind bands in their entradas. The Fallas and the Fogueres festivals cannot be understood without street band music, together with other types of festivities in which parades are always accompanied by wind bands.

All these activities also have a significant economic impact that makes musical societies an important resource for local development as they mobilise an important cultural industry. In fact, the direct economic effects of musical society activities were close to $€ 40$ million in 2018, representing $0.04 \%$ of the Valencian Region's GDP (Rausell, 2018, p. 29).

However, this economic importance is even greater if we take into account, firstly, the multiplier effect they have on other industries and related activities (music publishing, recording industry, musical instrument industry, education) with the expenditure of the musical societies, and, secondly all the "grey economy" generated around their activities that is not reflected in official figures. Thus, taking into account the indirect and induced effects, the total economic impact would be around $€ 60$ million (Rausell, 2018, p. 29). Therefore, musical societies can also be considered as a cultural cluster that has an enormous amount of material and human resources which, when they are actively encouraged, have very high transformation effects on the territory. 


\section{Moors and Christians Festivals and Music: An Inseparable Pair}

As commented above, Moors and Christians' representations were born as simulated danced battles and, as such, were accompanied by music. In fact, current Moors and Christians' dances are still accompanied by popular melodies interpreted with traditional instruments (GEA, 2010). Likewise, if we refer to former representations of Moors and Christians in the form of religious theatre, it was also common to accompany such representations with music to accentuate the educational and moralising sense of the representation (Lara Coronado, 2012).

At present, the musical genre for Moors and Christians is classified into liturgical works, processional works, martial works and evocative works (CipolloneFernández, 2017, pp. 227-228). The bulk of the repertoire consists of martial works, the type of music that is used basically in the entradas, which includes the three fundamental compositional modalities of the genre, i.e. pasodobles, ${ }^{9}$ Moorish marches and Christian marches (Botella-Nicolás, 2014, p. 333).

Although it is difficult to establish exactly when the transition from military music to specific music for Moors and Christians occurred (today, there are certain Moors and Christians festivals in which military marches are still played), there are references from the time when wind bands begin to participate in the Valencian Moors and Christians festivities. Thus, in 1817 in Alcoy, the Band of the National Militia Battalion was the first wind band to participate in an entrada of Moors and Christians (Botella-Nicolás, 2014, p. 334). Given that the first compositions created for the Moors and Christians festivities appeared in the last quarter of the nineteenth century, it is highly probable that the repertoire of the parades at that time included other types of popular compositions such as polkas, mazurkas and habaneras, in addition to military music (Botella-Nicolás, 2014, p. 334).

In the second half of the nineteenth century, there were already some Moors and Christians festivals with a complex structure of comparsas or filaes and with a clear interest in increasing the spectacular nature, splendour and ostentation of their parades (Ariño Villarroya, 1988, p. 40). This fact, together with the liking for orientalism and the exotic nature of musical romanticism, was key factor for the apparition of the first compositions designed for the Moors and Christians in the last third of the nineteenth century (Oriola Velló, 2012, p. 96). There is an open debate between authors who consider different composers from Alcoy (Alicante) as the precursors of music for Moors and Christians (Botella-Nicolás, 2013; Mansanet Ribes, 1987) and others who point out previous contributions by composers from other locations (Domene Verdú, 2018; Ferrero Pastor, 1987). In any case, the first compositions were basically pasodobles and Moorish marches. Although there are precedents from the late nineteenth century, the Christian marches developed later.

\footnotetext{
${ }^{9}$ Among the pasodobles composed for the Moors and Christians festival, there is one piece that has transcended the limits of the genre and has become a festive hymn throughout the world. It is the work known as "Paquito el Chocolatero", composed by Gustavo Pascual Falcó from Cocentaina (Alicante) in 1937.
} 
The first Christian march dates back to 1958, but its habitual use in entradas did not become widespread until at least two decades later.

There are five basic stages in the development of music for Moors and Christians. During the time of musical classicism (1899-1936), the festival assimilated music, that is, there was a period of adaptation between both elements. In the renovation period (1940-1957), styles were refined and the modern Moorish march appeared, with a more leisurely pace (Cipollone-Fernández, 2017, p. 220). Later, with the first Christian march, the golden age of Moorish and Christian music began and lasted until 1980. During this period, composers were concerned with historicity. Thus, religious overtones were introduced into the Christian march, and the warlike character of the compositions in which percussion takes centre stage was accentuated, giving a certain epic tone to the compositions.

Finally, the contemporary period of festive music, which began in 1980, is a particularly complex period in the musical sphere in which new musical languages have been incorporated. There is greater freedom in terms of musical structure and the influence of other genres, especially film music, is evident, with adaptations of numerous soundtracks. Special attention is paid to concert activity, and traditional instruments have been included in compositions and performances (Cipollone-Fernández, 2017, p. 223).

In this current period, composition activity has boomed, unusually, to the point that it has become difficult to absorb all the musical creations. One of the few formal approaches that have been made to catalogue the Moors and Christians festival repertoire dates back to 2001 and is estimated at more than three thousand works composed expressly for this festival, of which 1,936 have been catalogued (Francés Sanjuán, 2001). Since then, the number of compositions has grown exponentially. In any case, the figures suggested are part of the information put together by enthusiasts of the genre who have voluntarily collected data from personal websites and through social network profiles. Thus, according to these sources, the repertoire could be made up of around 6,000 compositions at present. ${ }^{10}$ Some musical societies are performing the interesting and much-needed task of compiling and digitising their musical databases. ${ }^{11}$ Institutions such as UNDEF have also tried to promote the creation of a musical archive in this area. One of the organisations that are working to showcase this very important cultural heritage is the Association of Composers of Music for Moors and Christians (ACMMICC, in its Spanish acronym), claiming that it is a genre that should have the same consideration as any other musical genre, both by the general public and by the composers and performers themselves (Pascual-Vilaplana, 2001).

\footnotetext{
${ }^{10}$ Some examples of these informal sources of information are websites (https://www.musicafes tera.com/obres or https://www.acordesfesteros.es/) and social network profiles (e.g. https://www. youtube.com/c/morosycristianos/featured).

11 This is the case, for example, of the Corporación Musical Primitiva de Alcoy (http://primigest. primitivadealcoi.org/archivo).
} 


\section{Final Reflections on the Economic, Cultural and Social Relevance of Music for the Moors and Christians Festivals}

Valencian musical tradition and, in particular, that of wind bands, as well as the Valencian Moors and Christians festivals, make up two cultural phenomena of an immaterial nature whose need for protection has been recognised by the Regional Government. Music for the Moors and Christians festivals is the element that links both phenomena, with implications from an economic, social and cultural point of view.

On a social level, the Valencian Region has the greatest presence of musical societies and Moorish and Christian festivals in Spain in which bands play a fundamental role in certain acts (entradas and other parades). Ironically, the moment in which the modern Moors and Christians festival finally established its festive model and when comparsas became widespread coincides approximately with a boom in the number of civil bands across Spain, though this was more significant in the Valencian region. Thus, the incorporation of wind bands into the Moors and Christians parades became commonplace, generating a relationship between bands and comparsas that transcends the commercial, especially in terms of the consolidation of music for Moors and Christians as a genre and its dependence on both parties for optimum development. In this sense, UNDEF and FSMCV signed a collaboration agreement in 2011 that recognised, on the one hand, the importance of the Moors and Christians festivals for the subsistence of a large number of musical societies in the Valencian Region, and on the other, the fundamental contribution of these musical societies to the Moors and Christians festivals, recognising the wind bands and the music for these festivals as being fundamental and essential elements of them (UNDEFFSMCV, 2011). Over time, both association movements have consolidated their roles as a point of contact between the different strata of society, becoming unique and differentiating features of the Valencian Region and a backbone of it.

In addition to the volume of the repertoire, the cultural and artistic value and impact that music has on Moors and Christians in the Valencian region are undeniable. The problem arises from the need for genuine recognition of this cultural and artistic value from all the stakeholders involved, whether we are talking about the general public, participants in festivals, the composers or the musicians themselves. Thus, the aforementioned UNDEF-FSMCV agreement recognised music for Moors and Christians as one of the most genuine manifestations of Valencian music, and established the unquestionable need for its study and promotion, granting it the dignity it deserves within the artistic and cultural context (UNDEF-FSMCV, 2011). Thus, the measures proposed in the agreement to respect the cultural and artistic value of the compositions included the formalisation of contracts with legally recognised musical societies. This aimed to guarantee proper training of the musicians, away from the intrusionism of certain informal groups of musicians formed ad hoc for specific events. It also established the need to have musical advisers on the comparsas' 
boards of directors, providing guidance on the vast possibilities of the existing repertoire, the minimum conditions that a band must have in order to adequately perform a work, etc.

From an economic point of view, the major impact that the Moors and Christians festivals and the activity of musical societies have on the Valencian economy has been corroborated. In this sense, a large part of the economic flows that are generated around the Moors and Christians festivals in a town is linked to the hiring of bands for musical accompaniment in parades or for the celebration of other activities which include concerts, recreational performances and recordings. In fact, the participation of the wind bands in the Moors and Christians festivals is not limited to entradas. It is very common for various Moors and Christians concerts to be organised in each town throughout the year, some of which are recorded. It is also common for wind bands to entertain brotherhood lunches and dinners. These activities make up a fundamental part of many musical societies' sources of funding. Studies on the economic impact of musical societies include the analysis of this kind of activities but not only in the case of music for Moors and Christians (Rausell, 2018, pp. 27-28). Therefore, it would be a very interesting exercise to disaggregate these data by genre in order to ascertain the real economic impact of this type of music. In fact, we hope that this work can provide a starting point to intensify research into music for the Moors and Christians festivals as intangible cultural heritage and its social and economic implications.

\section{References}

Alcaraz Santonja, A. (2019). La dimensió lúdica i transgressora de les festes de moros i cristians. Sociabilitat, diversió i espectacle en l'origen, evolució i expansió d'una festa moderna (18392018). Universitat d'Alacant - Universidad de Alicante, Alicante.

Amades, J. (1966). Las Danzas de Moros y Cristianos. Instituto de Estudios Ibéricos y Etnología Valenciana.

Ariño Villarroya, A. (1988). Festes, rituals i creences. Institució Valenciana d'Estudis i Investigació.

Botella-Nicolás, A. M. (2013). Orígenes de la música en las Fiestas de Moros y Cristianos de Alcoy. Revista de Folklore, 372, 28-38.

Botella-Nicolás, A. M. (2014). La música de Moros y Cristianos como patrimonio cultural y artístico. Posibilidades de trabajo en aula. Tejuelo: Didáctica de La Lengua y La Literatura Educación, 9, 331-349.

Botella-Nicolás, A. M. (2018). La riqueza de la música de Moros y Cristianos como patrimonio artístico y cultural II. Sociedad Latina de Comunicación Social.

Brisset Martín, D. E. (1988). Representaciones rituales hispánicas de conquista. Servicio de Publicaciones and Universidad Complutense de Madrid.

Brisset Martín, D. E. (2001). Fiestas hispanas de moros y cristianos (p. 17). Gazeta de Antropología: Historia y significados.

Catalá-Pérez, D. (2012). La fiesta de Moros y Cristianos: herencia cultural compartida entre España y América Latina. In A. Colomer Viadel (Ed.), América Latina, globalidad e integración I (pp. 407427). Ediciones del Orto.

Catalá-Pérez, D. (2017). La Fiesta de Moros y Cristianos y su extensión en todo el mundo: una visión abierta e integradora. In G. Ponce Herrero (Ed.), Moros y Cristianos: un patrimonio mundial. 
VI Congreso Nacional y I Internacional sobre la Fiesta de Moros y Cristianos. (pp. 29-45). Publicacions Universitat d'Alacant.

Cipollone-Fernández, A. (2017). Miguel Villar González (Sagunto 1913 - Gandía 1996) y su aportación a la música de las fiestas de Moros y Cristianos. Universidad de Alicante.

Cipollone Fernández, A. (2016). Gestión del patrimonio inmaterial: la presencia de la música para banda en los estudios académicos españoles. In E. Cutillas Orgilés (Ed.), La diversidad en la investigación humanística: $V$ Jornadas de Investigación de la Facultad de Filosofía y Letras de la Universidad de Alicante (pp. 157-166). Compobell.

Cohen, R. S. (1997). The musical society community bands of Valencia, Spain: A global study of their administration, instrumentation, repertoire and performance activities. Northwestern University.

Cohen, R. S. (1999). Community ensemble music as a means of cultural expression in the Catalanspeaking autonomies of Spain. In D. Dougherty \& M. M. Azevedo (Eds.), Multicultural Iberia: Language, literature and music (pp. 230-251). University of California Press.

Conselleria de Educación Investigación Cultura y Deporte. DECRETO 68/2018, de 25 de mayo, del Consell, por el que se declara bien de interés cultural inmaterial la tradición musical popular valenciana materializada por las sociedades musicales de la Comunitat Valenciana (2018).

Contreras Gay, J. (1992). Las milicias en el Antiguo Régimen. Modelos, características generales y significado histórico. Chronica Nova. Revista de Historia Moderna de La Universidad de Granada, O(20), 75-104. https://doi.org/10.30827/CN.V0I20.2741.

Domene Verdú, J. F. (2018). Las fiestas de moros y cristianos de Villena. Universidad de Alicante.

Dubois, V., Méon, J.-M., \& Bart, J.-Y. (2013). The sociology of wind bands. Amateur music between cultural domination and autonomy. The sociology of wind bands. Routledge. https://doi.org/10. 4324/9781315552644.

Ferrero Pastor, J. M. (1987). ¿Juan Cantó Francés o Camilo Pérez Laporta? Actas del I Centenario de la Música Festera de Moros y Cristianos, Cocentaina, 1982 (pp. 221-225). UNDEF.

Francés Sanjuán, P. J. (2001). El repertorio en la música para las fiestas de moros y cristianos (1882-2000). In I Encontre de Compositors de Música per a Moros i Cristians. Muro d'Alcoi.

GEA. (2010). Dance. Retrieved 16 September 2019, from http://www.enciclopedia-aragonesa.com/ voz.asp?voz_id=4549.

INE. (2020). Número de municipios por comunidad autónoma y provincia y tamaño de municipio. Retrieved 17 November 2020, from https://www.ine.es/jaxi/Datos.htm?path=/t20/e245/p04/ provi/10/\&file=0tamu001.px\#!tabs-tabla.

Lara Coronado, J. (2012). La educación moral en los autos sacramentales del siglo XVI en Nueva España. Perfiles educativos (Vol. 34). Instituto de Investigaciones sobre la Universidad y la Educación, UNAM.

Latorre Ruiz, Á. (2019). Análisis de la influencia socioeconómica de las fiestas de moros y cristianos en la ciudad de Alcoy. Universidad Politécnica de Valencia.

Mansanet Ribes, J. L. (1987). Aportación al origen y evolución de la música festera. Actas del I Centenario de la Música Festera de Moros y Cristianos, Cocentaina, 1982 (pp. 207-217). UNDEF.

Martínez Pozo, M. Á. (2015). Moros y Cristianos en el Mediterráneo Español: antropología, educación, historia y valores. Gami Editorial.

Martínez Puche, A., Martinez Puche, S., Ribera Sevilla, P., \& Esteban Buendía, J. (2019). Microcluster de la confección y alquiler de trajes de moros y cristianos en el contexto de los sistemas productivos tradicionales. El corredor del Vinalopó (Alicante) ¿Una transición resiliente? In International Conference on Regional Science. Asociación Española de Ciencia Regional.

Massip, F. (2015). Los Doce Pares de Francia en el México de hoy: vasos comunicantes con la teatralidad popular europea. In M. Ruiz Bañuls, J. L. V. Ferris, \& B. Aracil (Eds.), América Latina y Europa : espacios compartidos en el teatro contemporáneo (p. 539). Visor.

Mayor Catalá, B. (2011). Introducción a la Harmoniemusik. Sinfonía Virtual. Revista de Múascia Clásica y Reflexión Musical, (21). 
Molle, M. (2008). Approche Ethnologique et Ethnomusicologique de l'Univers des Bandas. Université Libre de Bruxelles.

Oriola Velló, F. (2012). Mísica i festa. Les societats musicals i les grans festivitats del poble valencià. In M. L. Del Cerro (Ed.), Arriben bandes. Les societats musicals valencianes (pp. 75-104). Museu Valencià d'Etnologia.

Parès, G. (1898). Traité d'instrumentation et d'orchestration à l'usage des musiques militaires d'harmonie et de fanfare. Henry Lemoine \& Cie.

Pascual-Vilaplana, J. R. (2001). La música de moros i cristians: història, vigència i defensa d'un gèner bandístic. In Simpòsium de música festera de la Vall d'Albaida.

Pascual-Vilplana, J. R. (2017). La normalización de la cultura bandística. Retrieved 17 November 2020, from https://www.pascualvilaplana.com/es/articulos/art/normalizacion-cultura-bandistica/ 39/pag/7.

Pascual-Vilaplana, J. R. (2011). Las bandas de música: vehículo de cultura para el siglo XXI. Retrieved 17 November 2020, from https://www.pascualvilaplana.com/es/articulos/art//15/ pag/11.

Pascual-Vilaplana, J. R. (2020). Tiempos de bandas. 125 Aniversario de la BM de Bilbao (18952020). Retrieved 17 November 2020, from https://www.pascualvilaplana.com/es/articulos/art/tie mpo-bandas/68/pag/1.

Pedrero Rico, G. (2016). Repercusión económica de las fiestas de moros y cristianos de Elda. Universidad de Alicante.

Perles Ribes, J. F. (2006). Análisis del impacto económico de eventos: una aplicación a fiestas populares de proyección turística. Cuadernos de Turismo, 17, 147-166.

Perles Ribes, J. F., \& Díaz Sánchez, E. (2019). Reestimación del impacto económico de las fiestas populares de proyección turística a través de metadatos provenientes de la telefonía móvil: Calp, un ejemplo de aplicación. PASOS Revista de Turismo y Patrimonio Cultural, 17(5), 947-961.

Rausell, P. (2018). Estructura, dimensión e impacto económico de las sociedades musicales. Universitat de València - FSMCV - Econcult.

Reily, S. A., \& Brucher, K. (Eds.). (2013). Brass bands of the world: Militarism, colonial legacies, and local music making. Brass bands of the world: Militarism, colonial legacies, and local music making. Routledge. https://doi.org/10.4324/9781315569895.

Rhodes, S. L. (2007). A history of the wind band. Lipscomb University.

The National Federation of Musical societies. (2017). An introduction to: Wind bands. Retrieved 22 November 2020, from https://www.makingmusic.org.uk/resource/introduction-wind-bands.

UNDEF-FSMCV. (2011). Convenio UNDEF - FSMCV para el establecimiento de unos acuerdos de mínimos que regularán las relaciones entre ambas entidades y sus asociados.

Warman Gryj, A. (1972). La danza de Moros y Cristianos. Secretaría de Educación Pública.

Open Access This chapter is licensed under the terms of the Creative Commons Attribution 4.0 International License (http://creativecommons.org/licenses/by/4.0/), which permits use, sharing, adaptation, distribution and reproduction in any medium or format, as long as you give appropriate credit to the original author(s) and the source, provide a link to the Creative Commons license and indicate if changes were made.

The images or other third party material in this chapter are included in the chapter's Creative Commons license, unless indicated otherwise in a credit line to the material. If material is not included in the chapter's Creative Commons license and your intended use is not permitted by statutory regulation or exceeds the permitted use, you will need to obtain permission directly from the copyright holder.

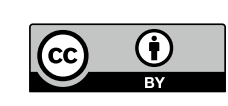

